\title{
The Influence of Progressive Muscle Relaxation Exercises on the Level of Anxiety an Athlete the High Jump
}

\author{
Eko Purnomo ${ }^{1 *}$, Suci Nanda Sari ${ }^{2}$, and Eddy Marheni ${ }^{3}$ \\ ${ }^{1,2,3}$ Dep. of Coaching, Faculty of Sport Science, Universitas Negeri Padang, Padang, Indonesia \\ "Corresponding author. Email: ekopurnomo@fik.unp.ac.id
}

\begin{abstract}
Competitive competition situations will raise anxieties for high jump athletes such as feelings of fear, tension, anxiety, difficulty concentrating and digestive disturbances that interfere with athlete's performance before the match. One simple and easy effort that can be done by athletes to reduce or reduce anxiety is to do fun and calming activities, one of them is by doing progressive muscle relaxation.This study aims to determine the level of anxiety reduction after a leap of relaxation progressively. This type of research is a quasi-experimental with a form of nonequivalent control group design. Samples totaled 55 people.The results obtained in this study can be seen as follows: The direct visible impact is, with progressive muscle relaxation exercises can provide comfort and relieve tension, and anxiety. Then, with a sense of anxiety that disappears, making the sample can make a better jump technically.Progressive muscle relaxation exercises can be done to give athletes a sense of confidence, especially for beginner athletes, as a form or an option in an exercise program. The exercises are very simple, so they can be followed or run by a trainer.
\end{abstract}

Keywords: Relaxation muscle progressive, high jump, anxiety

\section{INTRODUCTION}

Humans consist of unity of body and soul meaning that one part with another part influences each other, the influence felt by the soul will affect the body [1].In the sport training, commonly encountered that an athlete who has to prepare well for dealing with a sudden the experienced, indigestion so did not attend the match. It showed the symptoms immediately overcome, anxiety because it will hinder business athletes to got to play optimally and achieve a feat expected [2].

Exercise sports achievement it is not enough to physical exercise, engineering and maximum tactics to achieve a feat, but attention should be given to the others are mental training.An athlete who both in physical component, engineering and they did not necessarily maximum tactics.By therefore to be trained mental exercise may be a balance by other aspects.Mental skill is to strong foundation built in a person to prop scholastic achievement in the future [1].

Mental is one of the factors that must be considered in the process of training, as well as during athletes who show signs of anxiety when facing a match, including showing nervous behavior such as pacing on the sidelines, the state of heart pounding, wanting to urinate small, experiencing tension, irregular breathing, frequent drinking water, sweating cold, insomnia and often holding the head.Anxiety in sports is most common in a competitive sports environment and can also be called competitive stress. Lack of consensus makes it difficult for athletes to clearly define anxiety and stress in sports. Anxiety, or feeling physical and mental anxiety can be present in different ways, such as fear and nervousness [5]

Relaxation techniques can inhibit the sympathetic nervous stress response, the muscles of the arteries and veins along with other muscles in the body to relax [9]. One of the relaxation techniques as an effort to reduce blood pressure is with progressive muscle relaxation therapy (PMR).

Progressive Muscle Relaxation Exercise is a form of concentration exercise that involves the body's muscles directly in the process of implementation [6].Progressive Muscle Relaxation (PMR) is a form of relaxation therapy with the movement to tighten and relax the muscles of one part of the body at a time to gain control over anxiety that stimulates the mind and muscle tension [4].

Progressive muscle relaxation therapy is one of the relaxation techniques that can be used as stress management, where a person's stress conditions can affect his anxiety [3].Progressive muscle relaxation therapy can be applied directly to situations that can cause anxiety. It is expected that by using this therapy the problems that arise in athletes' physical and psychological symptoms due to anxiety can be overcome. 
The importance of relaxation training should be given by the coach to athletes in coaching sports achievements to get accustomed and able to distinguish between muscles that are in a tense state, and muscles that are in a relaxed state, before the athlete faces a situation full of tension.Relaxation exercises for athletes must be learned in a calm atmosphere and routinely trained before athletes are able to apply them in a stressful atmosphere.

Relaxation training must be learned by achievement coaching students, lest the trainer ask to relax in a tense state, but in the training process the trainer never gives relaxation exercises.Circumstances like that that occur so far in the process of training in sports. Mental training must be given clearly in accordance with the expected goals and how the practice in the field. Relaxation exercises must be given regularly in the training process, before the student is in a stressful or stressful situation when competing so that athletes while in training or competition can be more relaxed in a shorter time [7].

High jump is one type of athletic sport where athletes must make the highest jump over the bar without the aid of tools. The types of styles that are allowed in the high jump are scissor style, side bolster, straddle bolster, and flop or new styles that do not conflict with international rules.Of the four styles, all of them tend to make the high jump athlete jump from the left or right side to get their feet off the crossbar.

The risk of injury from high jump is far greater than long jump and outbreak, so it takes regular practice to get the right jump technique. High jump athletes especially beginners often feel anxious when facing competitive matches.Anxiety in this form of lack of confidence that results in excessive nervousness. Athletes feel they have great pressure when dealing with opponents. This makes the athlete less than optimal in making high jumps so that it allows athletes to not be able to cross the bar perfectly.

Taking into account the symptoms of anxiety that appear in athletes, the method of relaxation training, especially relaxation progressively it is important to be applied to reduce the various tensions felt by athletes when facing competitive matches. The importance of the coach's role in providing progressive relaxation training helps athletes stay comfortable when facing a championship. Thus, the performance of athletes on the field will run optimally.

\section{MATERIALS AND METHODS}

The research method used by the writer is quasiexperimental method (Quasi Experiment) with a population of 24 students. "The research method is a way to solve research problems that are carried out in a planned and meticulous manner in order to obtain facts and conclusions in order to understand, explain, predict and control the situation" [8]. Quantitative approaches are usually used to test a theory, to present a fact or describe statistics, to show the relationship between variables, and some are developing concepts.

The research method used by researchers in the form of an initial test (pretest) on the high jump number, the movement will be assessed by experts. In addition to the high jump movement / technique, the researcher will also assess the anxiety of the sample while doing the movement.After being given the initial test, the experimental sample will be given a treatment in the form of relaxation exercises to reduce anxiety when performing high jump movements.

The final action taken is to give a final test (posttest) the aim is to get a comparison of data from the initial test (pretest) to the final test (post-test). The following is the design of the one group pretest-post-test design. The following is the initial one-group pretestposttest design test model according to Syamsuddin and Damayanti (2011: 157). The one group pretest-posttest design.

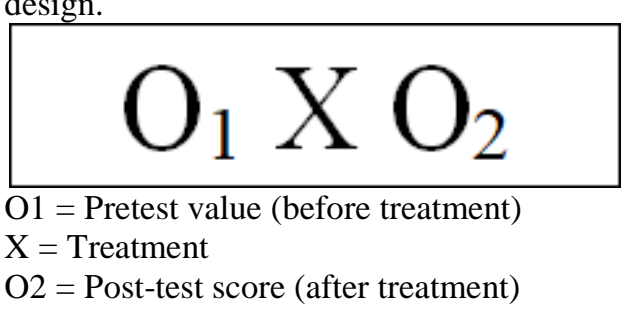

\section{RESULTS AND DISCUSSION}

The risk of injury from high jump is far greater than long jump and outbreak, so it takes regular practice to get the right jump technique. High jump athletes especially beginners often feel anxious when facing competitive matches.Anxiety in this form of lack of confidence that results in excessive nervousness. Athletes feel they have great pressure when dealing with opponents. This makes the athlete less than optimal in making high jumps so that it allows athletes to not be able to cross the bar perfectly.

Table 1. High Jump Pre-Test Results

Distribution of High Jump Ability Before Progressive Muscle Relaxation Exercises (Pre-Test)

\begin{tabular}{lll}
\hline Interval & Frequency & Percentage $(\%)$ \\
\hline $13-15$ & 3 & 5.45 \\
$16-18$ & 14 & 25.45 \\
$19-21$ & 15 & 27.27 \\
$22-24$ & 21 & 38.18 \\
$25-27$ & 2 & 3.64 \\
\hline Total & 55 & 100.00 \\
\hline
\end{tabular}


From these results it can be seen that the assessment of the high jump technique is still far from the appropriate value and is far from the maximum value that should be obtained. This is the basis of this research.

Table 2. Pre-Anxiety Test Results

Distribution of Anxiety Level (Anxiety) Before Progressive Muscle Relaxation Exercise (Pre-Test)

\begin{tabular}{lll}
\hline Interval & Frequency & Percentage $(\%)$ \\
\hline $20-27$ & 12 & 21.82 \\
$28-35$ & 8 & 14.55 \\
$36-43$ & 12 & 21.82 \\
$44-51$ & 18 & 32.73 \\
$52-59$ & 5 & 9.09 \\
\hline Total & 55 & 100.00 \\
\hline
\end{tabular}

Whereas if seen in this table, that the feeling of anxiety and fear to make the leap is very visible, it can also be concluded that the value of the results of the technique obtained is influenced by the anxiety of the testee who did. Another reason for testees to feel anxious is that they have never or haven't gotten material about high jumps, both at school and outside of school. Because in this study, the testee were new students in the Department of Training at the Faculty of Social Sciences, UNP. So, either technically or the anxiety experienced by the testee is still very bad and must be corrected in this research process.

In tables 1 and 2, it can be seen at a glance that, only a few testees who received a pretty good assessment, technically the implementation and anxiety are smaller, but that is only a little.

Tables 3 and 4 will see the results of the research that has been done. After treating the testee, the following research results can be obtained.

Table 3. High Jump Post Test Results

Distribution of High Jump Ability Before

Progressive Muscle Relaxation Exercises (Post-Test)

\begin{tabular}{lll}
\hline Interval & Frequency & Percentage $(\%)$ \\
\hline $25-29$ & 1 & 1.82 \\
$30-34$ & 11 & 20.00 \\
$35-39$ & 30 & 54.55 \\
$40-44$ & 12 & 21.82 \\
$45-49$ & 1 & 1.82 \\
\hline Total & 55 & 100.00 \\
\hline
\end{tabular}

In table 3 , we see an increase in the results of the testee jump technique in high jumping. Overall, that the treatment carried out was proven to improve the high jump technique. The basic comparison is that previously there were no testees who received ratings above 30 , and after being given treatment it can be said that overall there was an increase in the high jump technique. In addition, from the maximum value that can be obtained, there are several testees who are already close to that value.

Table 4. Post Anxiety Test Results

\begin{tabular}{lll}
\hline $\begin{array}{l}\text { Distribution of } \\
\text { Progressive Muscle Relaxation Exercise } \\
\text { (Pre-Test) }\end{array}$ & Before \\
\hline Interval & Frequency & Percentage (\%) \\
\hline $0-7$ & 15 & 27.27 \\
$8-15$ & 12 & 21.82 \\
$16-23$ & 22 & 40.00 \\
$24-31$ & 6 & 10.91 \\
\hline Total & 55 & 100.00 \\
\hline
\end{tabular}

In addition to an increase in the high jump technique that occurs, another result is obtained is a decrease in anxiety experienced by the testee, from before anxiety entered in the category of moderate to very heavy, at this time the testee's anxiety in high jumping was in the medium to not experiencing anxiety, meaning that confidence and comfort in jumping have been obtained by the testee.

\section{High Jump Results}

Bivariate analysis was performed to determine the effect of the independent variable (Progressive Muscle Relaxation Therapy) with the dependent variable (High Jump Results) indicated by a $\mathrm{p}$ value $<0.005$. Furthermore, to find out whether the research data is normally distributed before and after the intervention of progressive muscle relaxation therapy is given, the test in this study uses the Paired T-Test.This test is used to analyze the results of paired observations from data whether different or not, the data type interval or ratio, and the data are normally distributed. So the comparison test of the high jump test results pre test and post test used is the Paired T-Test. 
Table 5. Comparison Test Results for High Jump Pre-Test and Post-Test

\begin{tabular}{llllll}
\hline $\begin{array}{l}\text { High } \\
\text { jump }\end{array}$ & \multicolumn{2}{l}{ High Jump Result Rating Score } & $\begin{array}{l}\text { Sig. (2- } \\
\text { tailed) }\end{array}$ \\
\cline { 1 - 4 } & \multicolumn{3}{l}{ Pre Test } & \multicolumn{3}{l}{ Post Test } & \\
\cline { 2 - 5 } & Mean & SD & Mean & SD & \\
\hline $\begin{array}{l}\text { High } \\
\text { jump }\end{array}$ & 20.09 & 2,93 & 37,16 & 3,474 & $0,000^{*}$ \\
\hline
\end{tabular}

\section{Note: Paired t-test}

Based on table 8 with a statistical test with Paired T-Test in the pre-test and post-test $p=0,000$ or $p<0.05$ means that there are significant differences in the results of high jump before and after progressive muscle relaxation therapy.The above data can be seen that after doing progressive muscle relaxation exercises, there is an increase in the results of the assessment of jumps on the high jump on the testee, from before the average height jump exercise was carried out (mean) the testee reached 20.09 with the category of "low / bad" with STD Deviation 2.93. Then after being treated with progressive muscle relaxation therapy, the results obtained in the assessment of jumps in high jumps are on average (mean) reaching 37.16 with STD Deviation 3,474 . This means that the training provided provides an increase in the results of the jump.

\section{Anxiety Level}

Bivariate analysis was performed to determine the effect of the independent variable (Progressive Muscle Relaxation Therapy) with the dependent variable (anxiety level) indicated by a $\mathrm{p}$ value $<0.005$. Furthermore, to find out whether the research data is normally distributed before and after the intervention of progressive muscle relaxation therapy is given, the test in this study uses the Paired T-Test.This test is used to analyze the results of paired observations from data whether different or not, the data type interval or ratio, and the data are normally distributed. So the comparative test of anxiety level pre-test and post-test used is the Paired T-Test.

Table 6. Comparison Test Results for Pre-Test and Post-Test Anxiety Levels

\begin{tabular}{llllll}
\hline $\begin{array}{l}\text { Anxiety } \\
\text { Level }\end{array}$ & \multicolumn{3}{c}{ Anxiety Level Score } & $\begin{array}{l}\text { Sig. (2- } \\
\text { tailed) }\end{array}$ \\
\hline & \multicolumn{4}{c}{ Pre-Test } & \multicolumn{2}{c}{ Post Test } & \\
\cline { 2 - 5 } & Mean & SD & Mean & SD & \\
\hline $\begin{array}{l}\text { Anxiety } \\
\text { Level }\end{array}$ & 20.09 & 2,93 & 37,16 & 3,474 & $0,000^{*}$ \\
\hline
\end{tabular}

Note: Paired t-test
Based on table 8 with a statistical test with Paired T-Test in the pre-test and post-test $p=0,000$ or $p<0.05$ means that there are significant differences in anxiety levels before and after progressive muscle relaxation therapy.

The data above can be seen that after doing relaxation exercises, there is a decrease in anxiety in the testee, from before the relaxation exercises were carried out (the mean) testee anxiety reached 38.53 with the category of "Severe Anxiety" with STD Deviation 10.490. Then after being treated progressive muscle relaxation therapy, the results obtained are the average (mean) reached 14.60 with 8.601 STD Deviation. This means that the training provided has a positive impact.

\section{CONCLUSION AND SUGGESTION}

\section{A. Conclusion}

1. Progressive muscle relaxation exercises can provide high jump assessment results, from initially not good to better.

2. Progressive muscle relaxation exercises have a positive impact on testee anxiety when doing exercise.

3. The immediate impact is that progressive muscle relaxation exercises can provide a sense of comfort and relieve tension, and anxiety, then, with a sense of anxiety that disappears, making the testee can make a better jump technically jump.

4. This can be seen from the results of the research above.

\section{B. Suggestion}

1. This exercise can be improved to give athletes a sense of confidence, especially for beginners, as a form or as an option in an exercise program.

2. The training is very simple, so that it can be followed or run by a trainer or even a PJOK teacher especially in providing high jump material.

3. This exercise provides more comfort for the athlete to relax his muscles and make it more enjoy doing the jump.

4. The results of this study can be used as a reference and possible research resources and there is a possibility of having the same problem with researchers.

\section{REFERENCES}

[1] Arif Setiawan, Miftakhul Jannah, Wijono. 2018. The Effect of Progressive Relaxation Exercises on Reducing Anxiety in the Coaching of Takraw's Achievement. Surabaya: Universitas Negeri Surabaya Prosiding Seminar Nasional IPTEK Olahraga, 2018, ISSN 2622-0156 
[2] Dian Anggraini Kusumajati. 2011. The Relationship Between Anxiety To Face Competition With Achievement Motivation In Fencing Athletes in DKI Jakarta. Jakarta: Bina Nusantara University $H U M A$ NIO R A Vol.2 No.1 April 2011: 58-65

[3] Farida Maemunah Martiningsih, Retty Ratnawaty, Asti Melani Astari. 2018. Differences Effect Of Progressive Muscle Relaxation Therapy And Supportive Therapy On Parents Anxiety With Children Hospitalization At Rsud. Dr. R. Soedjono Selong East Lombok. Malang: Universitas Brawijaya Jurnal Ilmu Keperawatan, Vol. 6, No.1 Mei 2018

[4] Keliat, B. A. \& Pasaribu, J. 2016. Stuart Mental Health Nursing Principles and Practices. Singapore: Elsevier

[5] Stephani Yane. 2013. Anxiety in Sports. Pontianak: Pendidikan Jasmani dan Kesehatan STKIP PGRI PontianakJurnal Pendidikan Olah Raga, Vol. 2, No. 2, Desember 2013

[6] Sholikhin, Nurkholis, Miftakhul Jannah. 2019. Effects of Progressive Muscle Relaxation and Imagery Exercises on Archery Concentration, Anxiety and Accuracy. Surabaya: Universitas Negeri Surabaya Jendela Olahraga Volume 4, Nomor 1, 2019: Hal 18-25DOI: 10.26877/jo.v4i1.2952

[7] Shinde, et al., 2013. Immediate effect of Jacobson's progressive muscle relaxation in hypertension; Indian Journal of Physiotherapy and Occupational Therapy, Vol.7, no.3.

[8] Syamsuddin dan Damayanti. (2011). Language Education Research Methods. Bandung: Remaja Rosdakarya.

[9] Primasari Mahardhika Rahmawati, Musviro, Fitrio Deviantony. 2018. Effectiveness of Progressive Muscle Relaxation (PMR) on Reducing Blood Pressure in Patients with Hypertension. Jember:Fakultas Keperawatan Universitas The Indonesian Journal Of Health Science ISSN (Print) : 2087-5053 Edisi Khusus, September 2018 ISSN (Online) : 2476-9614 